\title{
Reactive Arthritis: Update
}

\author{
Ibtissam Bentaleb $^{1} \cdot$ Kawther Ben Abdelghani $^{2} \cdot$ Samira Rostom $^{1} \cdot$ Bouchra Amine $^{1} \cdot$ Ahmed Laatar $^{2} \cdot$ Rachid Bahiri $^{1}$
}

Accepted: 15 September 2020 / Published online: 26 September 2020

(C) Springer Nature Switzerland AG 2020

\begin{abstract}
Purpose of Review The aim of this paper is to provide an overview about reactive arthritis, with an update regarding pathophysiology and therapeutic approach of the disease, outlining the clinical features and diagnostic approach, based on recent literature review.

Recent Findings Reactive arthritis is considered to be part of the spectrum of the spondyloarthritis. Its epidemiology is changing worldwide due to several reasons, among them are as follows: different diagnosis approach and clinical presentations, different grades of infection, microbiome changes, etc. The understanding of pathophysiological models is challenging, but recent studies contribute to elucidate the major factors involved in the development of the disease. The management of ReA depends on the triggering agent and the phase of disease, whether it is acute or chronic.

Summary The association between the microbiome changes and spondyloarthropathies (ReA) is becoming increasingly evident. The results regarding the biologic treatment on refectory ReA are promising.
\end{abstract}

Keywords Reactive arthritis · Spondyloarthritis · HLA-B27 · Chlamydia-induced reactive arthritis

\section{Introduction}

Reactive arthritis (ReA) refers to a group of articular, entheseal, mucocutaneous, and ocular manifestations that occur after a genito-urologic, enteric, or respiratory infection.

This article is part of the Topical Collection on Bacteriology

Ibtissam Bentaleb

ib.bentaleb@gmail.com

Kawther Ben Abdelghani

kawther_ba@yahoo.fr

Samira Rostom

rostomsamira2003@yahoo.fr

Bouchra Amine

amine_bouchra@yahoo.fr

Ahmed Laatar

laatar.ahmed@rns.tn

Rachid Bahiri

bahirirachid@yahoo.fr

1 Service of Rheumatology A, El Ayachi Hospital, University Mohamed V Rabat, 11150 Salé, Morocco

2 Faculty of Medicine, Mongi Slim Hospital, University of Tunis EL Manar, 2046 Tunis, Tunisia
Generally, it is presented as an oligoarthritis usually following infection in the genitourinary (GU) or/and gastrointestinal (GI) tract $[1,2,3 \bullet \bullet$.

Recent studies related to ReA pathophysiology have highlighted the contribution of the microbiota in the pathogenesis of this type of arthritis $[1,3 \cdot \bullet, 4 \cdot]$.

In the USA, the frequency of reactive arthritis goes from 3.5 to 5 patients per 100,000 [2].

Due to the diversity in its clinical manifestations, the ReA diagnosis appears to be very challenging and may be missed in clinical practice [2].

There is a risk that ReA can lead to chronic destructive arthritis in the absence of specific management. In fact, an early diagnosis allows an early intervention which may avoid patients' complications [2].

\section{Is the Epidemiology of ReA Changing?}

There are different factors that stand behind the major shift in epidemiological data in ReA worldwide, among them are as follows: different diagnosis approach and clinical presentations, insufficient specific laboratory biomarkers, different geographical locations that predispose to multiple pathogens, different genetic backgrounds, different grades of infection, and microbiome changes observed recently $[1,4 \cdot 5]$. 
Usually ReA arises in young population, particularly between 18 and 40 years old, with peak between the age of 20 to 29 years $[2,6 \bullet]$. Nevertheless, children are also considered a target, but the prevalence of juvenile ReA is very low $[3 \bullet \bullet, 7]$.

The risk of developing ReA post-enteric infections is similar between men and women [8]. But, Townes et al. have stated that relative risk RR is higher for women (RR $1.5 \mathrm{vs.}$ males) and adults (RR 2.5 vs. children) [9]. However, when it comes to genitourinary infections, the risk is higher for men than women with 9:1 ratio [1]. Another study has shown that females are more exposed than male [10].

The condition also is more common in white patients, as the presence of the HLA-B27 gene is higher in them than in patients of other ethnicities [7].

The rate of incidence and prevalence of ReA varies worldwide according to three factors (geography, pathogens, and presence of HLAB27) [7].

The worldwide prevalence of ReA in adults is cited as $1 / 1000$, although this varies geographically [7]. For instance, Scandinavian countries have recorded a higher prevalence of ReA with greater HLA B27 positivity, whereas Indonesia, the Philippines, and Malaysia have a lower prevalence with less HLA B27 frequency [7] (Tables 1).

The annual incidence of ReA post-enteric infection is estimated to reach one per 1000 according to a recent study [6 $6^{\bullet}$, while its frequency changes dramatically from 1 to $15 \%$ among studies due to different study designs and outcome definitions [12]. According to the recent meta-analysis of Ajene et al., ReA post-enteric infection incidence varies from 0 to $16 \%, 0.1$ to $29 \%$, and 0 to $12 \%$ for Campylobacter, Salmonella, and Shigella infections, respectively [13]. When it comes to genitourinary infections, we can notice a recent decrease in incidence of sexually acquired reactive arthritis (SARA) due to campaigns to raise awareness about sexually transmitted disease. Denison et al. have reported an incidence of SARA between 3.0 and $8.1 \%$ [14].

Regarding the Middle East and Africa region, the scarcity of epidemiological data has prevented researchers from estimating the prevalence of $\operatorname{ReA}[11,15,16]$. Given the fact that sexually transmitted diseases are prevalent in Africa, with a high rate of the human immunodeficiency virus (HIV) [15, 17], SARA is increasing in this area [14]. For instance, a study conducted in Zambia has demonstrated that the prevalence of spondyloarthritis $(\mathrm{SpA})$ was higher in patients with HIVpositive rather than those who tested HIV-negative (respectively, 180 per 100,000 and 15 per 100,000) [18].

Concerning Chlamydia-induced ReA (CiReA), a multinational comparative study in three North African countries (Morocco, Algeria, and Tunisia) has shown that the prevalence of the disease in North Africa is very low (10\%) compared with Western Europe and the USA [16].

Since gastrointestinal infections are related to water and food contamination, the prevalence of ReA post-enteric infections is probably high in third world countries but still underestimated [11].

Reactive arthritis typically occurs in sporadic cases but may occur with increased frequency in the setting of outbreaks of infection [8].

\section{What Are the Pathophysiologic Model Advances?}

The physiopathology of ReA is a very complex process, reflecting a dynamic interface between environmental triggers and a genetic susceptibility [6•]. In fact, the development of ReA depends on four major factors: infection history

Table 1 Incidence and prevalence of ReA according to the different studies

\begin{tabular}{|c|c|c|}
\hline Country & $\operatorname{ReA}$ & Study \\
\hline Spain [1] & $n=16 / 1168,1.4 \%$ of $\operatorname{ReA}$ & emAR II study. Casal-Schanzes et al. 2012 \\
\hline $\begin{array}{l}\text { Czech Republic } \\
\text { [2] }\end{array}$ & $\begin{array}{c}\text { Annual incidence }=9.3 / 100,000 \\
\text { prevalence }=91.3 / 100000\end{array}$ & Descriptive population-based study 2002-2003 Hannova et al. \\
\hline $\begin{array}{l}\text { Central America } \\
{[3 \cdot \bullet]}\end{array}$ & $47.2 \%$ & $\begin{array}{l}\text { Retrospective cohort of } 233 \text { spondyloarthropathy patients in } 2 \text { centers in } \\
\text { Guatemala City and Costa Rica } \\
\text { García-Kutzbach et al. }\end{array}$ \\
\hline Sydney $[4 \bullet]$ & $\begin{array}{l}\text { Incidence of ReA } \\
1992-1996=113 / 1,000,002,007-2011=13 / 100,000\end{array}$ & $\begin{array}{l}\text { Case control study of ReA at the Sydney Sexual Health Centre over the } \\
\text { period 1992-2012 Mason et al. }\end{array}$ \\
\hline North Africa [5] & $\begin{array}{l}8 / 56 \text { of } \operatorname{ReA} 6 \text { posturethritic, } 2 \text { postenteritic } \\
\text { Algeria } 1 / 56 \\
\text { Morocco } 4 / 56 \\
\text { Tunisia } 3 / 56\end{array}$ & $\begin{array}{l}\text { A cohort of North African patients with reactive arthritis, undifferentiated } \\
\text { arthritis, rheumatoid arthritis (RA), and osteoarthritis (OA) Kipper et al }\end{array}$ \\
\hline Morocco [11] & $13 \% \operatorname{ReA}$ & N. Hajjaj-Hassouni \\
\hline Morocco & $1-2$ cases of $\mathrm{ReA} / \mathrm{year}$ & R. Bahiri (survey) (unpublished) \\
\hline
\end{tabular}


(etiological agents), the role of cytokines, the involvement of genetic factor (HLA-B27), and gut microbiota [6•].

\section{Etiological Agents in Reactive Arthritis}

Some bacteria are commonly known to be triggers of ReA. They may attain the joints through intestinal or genitourinary infections $[1,8]$. Moreover, it has been proven that the synovial tissue or fluid may contain bacterial antigens, and the persistence of these components can turn acute ReA into chronic arthritis [6•]. Indeed, recent investigations indicate that synovial fluid of ReA patients contains immunogenic products like bacterial DNA, antigenic proteins, and lipopolysaccharides [4•].

There are several features in common between all these pathogens: they can infiltrate mucosal surfaces and replicate intracellularly as well as contain lipopolysaccharide in their outer membrane $[3 \cdot \bullet]$.

In ReA genitourinary transmission, Chlamydia trachomatis $(\mathrm{Ct})$ is the most common cause followed by Ureaplasma urealyticum and other less common germs [1].

\section{Chlamydia-Induced Reactive Arthritis}

Studies have shown that Chlamydia trachomatis $(\mathrm{Ct})$ is a very common pathogen that causes ReA. In fact, $50 \%$ of patients with ReA genitourinary infections have been diagnosed with $\mathrm{Ct}[3 \cdot \bullet]$. Moreover, $\mathrm{CDC}$ data estimates that three million new $\mathrm{Ct}$ infections are recorded every year in the USA [3••].

It has been demonstrated that chronic inflammation is caused by bacterial components of persistent $\mathrm{Ct}$ [19]. This can be explained by the Ct's capacity to inhibit the combination of phagosomes and lysosomes which makes Chlamydia persistent in cells $[4 \bullet, 6 \bullet]$. Droemann et al. have suggested that persistence may represent the host's attempt at containing Chlamydia, with disease flares being related to chlamydial escape from persistence leading to acute inflammatory events [20].

\section{Host Response and the Role of Cytokines in ReA}

The bacterial antigens are transported from the primary site into the synovial membrane after local bacterial infection, which causes the activation of T-lymphocytes and consequently the release of inflammatory cytokines, resulting in synovial inflammation $[4 \cdot, 6 \bullet]$.

The previous studies have stated that inflammatory cytokines such as tumor necrosis factor-alpha (TNF- $\alpha)$ and interferon-gamma (IFN- $\gamma$ ) were reduced in the case of acute ReA [21]. Another study confirmed this finding by proving that in the synovial fluid of $11 \mathrm{ReA}$ patients, a large amount of IL-10 was secreted, whereas only a small amount of IFN- $\gamma$ and TNF- $\alpha$ was observed [22]. Conversely, other studies showed that TNF- $\alpha$ levels may be elevated in chronic ReA [23], which suggests a dual role of this cytokine in different stages of disease pathogenesis [3••].

Studies have shown that IL-17 levels were found in the synovial fluid of CiReA patients [3••]. A different study focusing on patients with type S. typhoid ReA showed that Salmonella adventitia proteins could stimulate the synovial immune cells to produce IL-17 or IL-23 [24]. Another recent study of patients with ReA due to $S$. typhimurium suggests that Salmonella outer membrane protein is able to stimulate interleukin (IL)-17/IL-23 production in synovial immune cells [24].

\section{Genetics: Role of HLA-B27 in ReA}

Admittedly, the association between HLA-B27 and ReA is well known, but its involvement in pathogenesis is still confusing.

Studies have shown that the prevalence of positive HLA B27 ranges from 50 to $80 \%$ in patients with ReA and $90 \%$ of the cases with ankylosing spondylitis (AS) $[2,4 \cdot, 6 \bullet, 15,25]$.

It has been suggested that HLA-B27 may influence the host response. For instance HLA-B*2703 increases the risk of the typical clinical triad of ReA [26]. Furthermore, the persistence of causative agents, especially Chlamydia and Salmonella, in the host may be due to the involvement of HLAB27 [27, 28]. It has been found in a study by Antoniou et al. that both expressions of HLAB27 and HLA-B27 misfolding are responsible for the enhancement of the bacterial replication [29]. Also the findings assess that HLA-B27 expression can reduce the threshold of endoplasmic reticulum (ER) stress induction and that Salmonella can induce the unfolded protein response [29].

According to many studies, the findings were as follows $[3 \bullet \cdot, 30,31]$ :

- HLA-B27 folds more slowly than other types of HLA in ER assembly, which results in the accumulation of the HLA-B27 homologous dimer and b2-microglobulin and activates the inflammatory process.

- Current studies have proposed a number of theories, among them the theory of molecular mimicry between the gene and the pathogen. Indeed, it has been proven that there is a similarity between amino acid sequences in HLA-B27 and Yersinia or Shigella proteins leading to cross-reactivity, tolerance, and hence persistence of the organism.

\section{Gut Microbiota and ReA}

In recent years, there has been a growing interest in the gut microbiome and its implication in the pathogenesis of arthritis 
[3••]. In fact, new studies are focusing on highlighting the association between the microbiome and SpA as well as other inflammatory arthritis [1].

It has been suggested that the altered microbiota may result in aberrant immune responses to gut flora, gut dysbiosis, inflammation, and thus to $\operatorname{SpA}[8]$.

Inflammatory bowel disease, psoriasis, and $\mathrm{SpA}$ are all characterized by gut dysbiosis. While all of these conditions show decreased gut bacterial diversity, this is not the case in $\operatorname{ReA}[3 \bullet \bullet],[4 \bullet]$. In a study that compared patients with $\operatorname{ReA}$ with those with prior infections who did not go on to develop arthritis, no significant differences were seen in gut bacterial diversity between the groups [4•]. Erwinia and Pseudomonas as well as Salmonella, Shigella, and Campylobacter were significantly higher in abundance in ReA than in controls [4•].

Some research states that the prevalence of enteropathogens was high in subjects with ReA and postinfectious peripheral $\mathrm{SpA}$. The research also reported a decrease in gut commensals $[1,4 \bullet]$.

In the same context, J. Manasson et al. revealed that patients with ReA had a low abundance of commensals in their gut microbiota compared with controls [4•]. Guts of ReA patients were enriched in the family Lachnospiraceae with associated genera Blautia, Coprococcus, and Roseburia, as well as the genus Collinsella [4•]. In the ReA group, the prevalence of enteropathogens showed an increase, specifically concerning Pseudomonas and Erwinia [4•]. This is a taxon that has $\geq 97 \%$ identity with the usual ReA-associated gut bacteria such as Salmonella, Shigella, and Yersinia [4•].

\section{What Are the Clinical Manifestations of ReA?}

It is generally known that ReA and SpA belong to the same family of inflammatory syndrome [3••]. In fact, Kaarela et al. have shown through their study that chronic ReA and AS have the same clinical manifestations such as sacroiliitis, peripheral arthritis, and iritis $[15,32]$.

The most common clinical pattern of ReA is typically the acute form. Some patients recover spontaneously within the first 6 months, while others (10 to $30 \%$ of patients) tend to develop a chronic ReA [33].

Generally speaking, depending on the form (acute or chronic), ReA is characterized by articular and extraarticular symptoms.

\section{Osteoarticular Manifestations}

The most frequent presentation of $\mathrm{ReA}$ is the oligoarthritis. For instance, Ali et al. revealed in their study that the oligoarticular mode of illness is the most prominent with a figure of $70 \%$ in female (F) and $73 \%$ in male (M), followed by monoarticular (13\% (F), 14\% (M)) and polyarticular (14\% (F), 10\% (M)) mode of illness presentation [34].

ReA can affect any peripheral joint, but the knee is considered to be the most involved. As demonstrated by Ali et al., the joints that are affected the most are respectively knee (64.7\% (F), 52.12\% (M)), talocrural joint (50\% (F), 57\% (M)), metatarsophalangeal joint (41\% (F), 48\% (M)), and radiocarpal joint (44\% (F), 48\% (M)) [34]. Recently, according to Manasson et al., $100 \%$ of patients with ReA had peripheral arthritis with an average tender joint count of 5 [4•].

According to the literature, the axial manifestations might be under-recognized [35]. However, a study revealed that low back pain was seen as an initial symptom in $49 \%$ among patients with ReA vs. $28 \%$ of patients with psoriatic arthritis (PsA) [35]. The same study has shown that $14 \%$ of patients with ReA presented with sacroiliitis compared with $7 \%$ with PsA [35]. Furthermore, the radiographic sacroiliitis (grade 24) was observed in $23 \%$ of patients with chronic ReA, while syndesmophytes was seen in 14\% of them [36]. Manasson et al. have shown that $56.3 \%$ of subjects with ReA have radiographic sacroiliitis mostly grades 1 and 2 compared with control $(50 \%)[4 \bullet]$.

It has been suggested that enthesitis is more common than synovitis in patients with ReA [9]. As documented, the prevalence of enthesitis ranges from 30 to $60 \%$ in patients with chronic CiReA [1]. The study of Manasson et al. has recorded achilles enthesitis among 14 patients with ReA (43.8\% ReA, $6.3 \%$ controls) $[4 \cdot]$.

\section{Extra-Articular manifestations}

- Genitourinary symptoms: May include urethritis, cervicitis, salpingo-oophoritis, cystitis, or prostatitis. In the postvenereal form of ReA, urethritis and cervicitis are the most observed symptoms. Courcoul et al. have reported in a retrospective study that a total of $7 \%$ of patients with ReA have circinate balanite [37]. Another study estimates that approximately $80 \%$ of men with SARA have urethral discharge and/or dysuria [38].

- Ocular symptoms: Conjunctivitis is more seen in patients with acute ReA and arises rarely in chronic disease [39]. In fact, conjunctivitis is reported in $51 \%$ of patients with $\operatorname{ReA}$ [39]. Nevertheless, uveitis is more often observed in the chronic ReA but less frequently seen in the acute ReA [39]. In the same Russian cohort, uveitis was the most common ocular symptom among chronic ReA patients [39]. Manasson et al. have also demonstrated a high rate of uveitis in ReA subjects compared with controls $(62.5 \%$ vs. $6.3 \%)[4 \bullet]$.

- Skin manifestations: The most observed are keratoderma blennorrhagicum, circinate balanitis, aphthous ulcers (up to $60 \%$ ), and erythema nodosum (rare). Keratoderma blennorrhagicum arises in $20 \%$ of ReA patients [3••]. 
Circinate balanitis is seen in $10-40 \%$ of ReA cases [37, 40]. Onycholysis and pitting occur in about $10 \%$ of patients [40].

- Cardiac manifestations: It has been suggested that pericarditis is more seen in chronic stage of ReA, while heart block and valvular disease may arise in the acute ReA [41].

\section{How to Make a Diagnosis of ReA?}

To date there is no agreement regarding ReA diagnostic criteria. Consequently, the diagnosis is essentially clinical, based on a careful history and physical examination [8]. They will elicit symptomatology of prior infection and can yield evidence of musculoskeletal involvement and/or extraarticular infections. The rheumatologists must also seek SpA evolutive symptoms.

Given the many clinical manifestations of ReA, and the urgency of some differential diagnoses, clinicians must consider excluding the most common ones such as septic arthritis, gout, psoriatic arthritis and rheumatoid arthritis [8].

\section{Diagnostic Criteria}

Although there is an absence of a consensus regarding $\mathrm{ReA}$ diagnostic criteria in the majority of cases, the diagnosis of ReA is established on the association of clinical and microbiological criteria [37].

During the fourth International Workshop on ReA, Berlin, Germany, in 1999, the lists of general guidelines concerning the classification and diagnosis of ReA have been issued [42] (Table 2).

- Patients with definite diagnosis of ReA must have both major criteria and at least one minor criterion.
- Patients with probable diagnosis for ReA must have both major criteria or one major and one minor criterion.

\section{Laboratory Testing}

\section{Confirmation of Triggering Infection}

Enteric pathogens as Campylobacter, Salmonella, Shigella, or Yersinia can be detected usually by a combination of enzyme immunoassay and culture of stool [8].

In order to diagnose $\mathrm{Ct}$ infection, several techniques are used among them:

- Nucleic acid amplification of urine or a urethral swab specimen.

- Urinary PCR can detect rapidly Ct. DNA, as demonstrated by Sharma et al. in their recent study where $36 \%$ of $\operatorname{ReA}$ patients have $\mathrm{Ct}$ in their urinary samples [43].

- Kumar et al. have found that semi-nested PCR (snPCR) and nested PCR (nPCR) are used to detect Ct DNA in synovial fluid in their recent study [44].

Even if the polymerase chain reaction analysis has demonstrated its efficacy in the detection of the causative organisms or degradation products, it is still not accessible for the most physicians.

Antibody testing may also be used to identify in particular, but positive serologies often do not distinguish between remote and recent infection. In addition, serology results are often delayed by several days after collection, limiting clinical usefulness [8].

\section{Inflammatory Markers}

In the acute phase of ReA, the inflammatory markers such us erythrocyte sedimentation rate (ESR) and CRP tend to be
Table 2 Diagnosis criteria of ReA issued during the fourth International Workshop on Reactive Arthritis, Berlin, Germany, in 1999

\begin{tabular}{|c|c|}
\hline Major criteria & Minor criteria \\
\hline $\begin{array}{l}\text { 1-Arthritis, meeting } 2 \text { of the following } 3 \\
\text { characteristics: } \\
\sqrt{ } \text {. Asymmetric } \\
\text { V. Mono- or oligoarthritis } \\
\sqrt{ } \text {. Lower limb involvement } \\
\text { 2-Preceding symptomatic infection, meeting one of } \\
\text { the following characteristics: } \\
\sqrt{ } \text {. Enteritis, defined as at least } 1 \text { day of diarrhea } \\
\text { occurring } 3 \text { days to } 6 \text { weeks before the onset of } \\
\text { arthritis } \\
\sqrt{ } \text {. Urethritis, defined as dysuria or discharge for at } \\
\text { least } 1 \text { day occurring } 3 \text { days to } 6 \text { weeks before the } \\
\text { onset of arthritis }\end{array}$ & $\begin{array}{l}\text {-Presence of a triggering infection, as evidenced by } \\
\text { positive urine culture, cervical/urethral swab, or } \\
\text { stool culture } \\
\text {-Presence of persistent synovial infection, as } \\
\text { evidenced by positive immunohistology or PCR }\end{array}$ \\
\hline
\end{tabular}


higher [2]. However, in CiReA we can observe normal rate in acute phase reactant including (ESR and CRP) [45].

\section{Radiological Findings}

There are no specific diagnostic tests to confirm this disease. However, there are more publications that have reported the benefits of ultrasound in SpA especially the diagnosis of ReA $[1,46]$. For instance, H. Yoshimura has stated in his case report that the diagnosis of ReA was supported by ultrasonographic findings of enthesitis and synovitis [47].

\section{What About the Therapeutic Approach?}

With regard to treatment, the underlying infections, articular and extra-articular disease manifestations, should be considered while setting the management of ReA. The treatment of the underlying infections depends on the type of triggering infection $[3 \cdot \bullet]$.

The management of ReA depends on the phase of disease, whether it is acute or chronic.

\section{Treatment of Acute ReA}

\section{Non-steroidal Anti-inflammatory Drugs}

NSAIDs are considered to be the first-line drugs for SpA and ReA management [8]. According to physicians' experiences, NSAIDs have proved their clinical efficacy in the treatment of ReA, even if only two small prospective trials have formally evaluated their use $[3 \bullet \bullet]$.

The first study was conducted in the UK on patients with PsA and ReA and compared azapropazone with indomethacin [48], while the second one compared ketoprofen with indomethacin [49]. Both studies have shown the effectiveness of NSAIDs on peripheral arthritis.

We consider that ReA is unresponsive to NSAIDs when at least two different NSAIDs fail, each given in the maximal dosage and for at least 2 weeks [50].

\section{Glucocorticoids}

For patients with acute ReA, who respond inadequately to or do not tolerate NSAIDs, intra-articular glucocorticoid therapy should be considered, provide symptomatic relief, and spare potential side effects of systemic steroids $[1,8]$.

\section{Antibiotic}

Regardless of the several studies on antibiotics as a therapeutic approach for ReA, there is still a debate about their effectiveness $[3 \bullet \bullet$.
In his meta-analysis, Barber et al. stated that antibiotic treatment did not show a benefit for ReA but might have negative side effects [51].

The same results were found by Kuuliala et al. where 3month treatment with the combination of ofloxacin and roxithromycin did not show any effect on the recovery from arthritis for patients in recent-onset ReA [52].

In the same context, Courcoul et al. have shown that antibiotic therapy is not effective since it was abandoned in the second cohort 2002-2012 comparing with the first one 19861996 (half of cases using antibiotic) [37].

However, Carter et al. have demonstrated that patients with chronic CiReA have higher response rate to a 6-month course of combination of antibiotics (doxycycline or azithromycin, combined with rifampin) in comparison with placebo [53].

\section{Chronic ReA}

\section{Disease-Modifying Antirheumatic Drugs}

There is a similarity between radiographic damage of ReA and other type of SpA, PsA in particular. For these reasons, traditional DMARDs are often utilized in patients with ReA [1, $3 \cdot \bullet, 50]$.

Sulfasalazine (SSZ) proved its efficacy in treatment of ReA that has been analyzed in two prospective, double-blind studies $[54,55]$.

Methotrexate (MTX) is considered to be the most used DMARD to treat patients with chronic ReA, even if clinical trials did not prove its efficacy [3・•].

\section{Biological Agent}

The results of biological treatment on refractory ReA are promising even if studies conducted in this field are generally case reports and small-scale open clinical trials. Patients who were treated with biological treatment have shown symptom relief and improvement of inflammatory markers of arthritis [6•].

TNF Alpha Antibody Regarding the pathophysiology of ReA, studies have shown that TNF- $\alpha$ levels may be elevated in chronic ReA [23], which explains the use of anti TNF alpha as a therapy approach.

When ReA is refractory to well-conducted conventional therapy (NSAIDs and DMARDs) or has progressed for 6 months, then anti-TNF alpha are indicated [37, 56].

For instance, the study conducted by Meyer et al. on patients with refractory ReA and treated with anti-TNF antibodies (infliximab, etanercept, and adalimumab) has revealed the clinical and biological effectiveness of this treatment, without showing any serious adverse events [57]. The same were reported by other studies $[8,30,53,58]$. 
Interleukin-6 Receptor Antibody According to the case report of Tanaka et al., using tocilizumab improves quickly the symptoms of ReA that does not respond to traditional drugs. This is the first case confirming the efficacy of tocilizumab in treating $\operatorname{ReA}[59]$.

Interleukin-17a Monoclonal Antibody Few trials and reports have been conducted on IL-17a monoclonal antibodies in ReA. In one study, secukinumab was used to treat one case of active ReA. The clinical symptoms improved rapidly, and no serious adverse event occurred in the 12-week study [8]. According to the study of Mens et al., secukinumab has shown good results in treating peripheral $\mathrm{SpA}$ active cases without serious adverse effects [60].

\section{Evolution and Prognosis}

Generally, the course of ReA is highly variable, whether it is disease duration, frequency, or severity of relapses. As suggested, most patients have completed remission within 612 months [8]. However, 30 to $63 \%$ of patients develop chronic $\mathrm{ReA}$ remaining more than 6 months and require retreatment. Some of these patients may develop signs and symptoms of AS or inflammatory bowel disease [8].

As demonstrated by Mens et al. out of 62 ReA patients, only 42 beneficiate from a follow-up of 34 months, $52 \%$ of these patients were in remission, under or without treatment, and $44 \%$ developed SpA and 4\% PsA [61].

Courcoul et al. have shown that more patients completely recovered in the 1986-1996 cohort (42\% vs. 26\%), while more patients developed spondyloarthritis in the 2002-2012 cohort (16\% vs. $55 \%$ ). Moreover, $80 \%$ of patients who developed spondyloarthritis were HLA-B27+ compared with $10 \%$ HLA-B27- [37].

Regarding the predictive factors of worse prognosis of ReA, HLA-B27 positivity, Chlamydia-induced infection, spondyloarthropathy family history, and chronic bowel inflammation were the factors that contribute the most to severity and progression of the disease [61].

\section{ReA and COVID-19}

Since December 2019, the pandemic caused by COVID-19 raises a real public health problem [62]. In the course of time, clinicians worldwide experienced several different forms of COVID-19 [63].

Elif et al. have reported the first case of ReA associated with COVID-19 infection in Turkey. It was a 73-year-old man with diabetes mellitus, hypertension, and coronary heart disease, presented to emergency department with a history of fever, weakness, and dry cough for 1 week. Nasopharyngeal and oropharyngeal swabs were positive for COVID-19 [63].

He was treated with ceftriaxone, hydroxychloroquine, and azithromycin. Several days after completion of COVID-19 treatment, asymmetric oligoarthritis in his lower extremities was developed. Because of a typical pattern of clinical presentation of arthritis and the evidence of COVID-19 infection in the preceding 2 weeks, the patient was diagnosed with ReA caused by COVID-19. After NSAID treatment, the symptoms of arthritis were completely resolved [63].

This finding raises the awareness of the physicians in general and rheumatologist in particular; thus, more investigations are needed to understand the association between this rheumatic disease (ReA) and COVID-19.

\section{Conclusion}

ReA is a part of the SpA family. Its diagnosis is established on the association of clinical and microbiological criteria. The involvement of gut microbial dysbiosis in disease pathogenesis remains unclear; thus, further productive researchers are needed to close these knowledge gaps in the field. The progression of ReA towards chronicity explains the necessity of an early rheumatologic management and follow-up with appropriate treatment.

\section{Compliance with Ethical Standards}

Conflict of Interest The authors declare that they have no conflicts of interest.

Human and Animal Rights and Informed Consent This article does not contain any studies with human or animal subjects performed by any of the authors.

\section{References}

Papers of particular interest, published recently, have been highlighted as:

- Of importance

•- Of major importance

1. García-Kutzbach A, Chacón-Súchite J, García-Ferrer H, Iraheta I. Reactive arthritis: update 2018. Clin Rheumatol. 2018;37(4):86974.

2. Pennisi M, Perdue J, Roulston T, Nicholas J, Schmidt E, Rolfs J. An overview of reactive arthritis. J Am Acad Physician Assist. 2019;32(7):25-8.

3.• Espinoza LR, editor. Infections and the rheumatic diseases. Cham: Springer International Publishing; 2019 [cited 2020 May 9]. Available from: http://link.springer.com/10.1007/978-3-03023311-2. This book highlight the importance of infectious agents in the etiology and pathogenesis of musculoskeletal disorders including Reactive arthritis, as well as the role they 
play in affecting the natural course, disease expression, progression, and clinical response to conventional and biological therapy.

4. Manasson J, Shen N, Ferrer HRG, Ubeda C, Iraheta I, Heguy A, et al. Gut microbiota perturbations in reactive arthritis and postinfectious spondyloarthritis. Arthritis Rheumatol Hoboken NJ. 2018;70(2):242-54 This study clarifies the pathophysiology of $\operatorname{ReA}$ by showing the characteristic of the gut microbiota for post infectious arthritis patients.

5. Gupta R, Misra R. Microbe-triggered arthropathies: reactive arthritis and beyond. Int J Rheum Dis. 2016;19(5):437-9.

6. Zeng H, Luo B, Zhang Y, Xie Z, Ye Z. Treatment of reactive arthritis with biological agents: a review. Biosci Rep. 2020 [cited 2020 May 9];40(2). Available from: https://www.ncbi.nlm.nih. gov/pmc/articles/PMC 7033307/. this article has summarized the current publications that emphasize the safety and efficacy of biological agents on the treatment of refractory ReA.

7. Hayes KM, Hayes RJP, Turk MA, Pope JE. Evolving patterns of reactive arthritis. Clin Rheumatol. 2019;38(8):2083-8.

8. Schmitt SK. Reactive arthritis. Infect Dis Clin North Am. 2017;31(2):265-77.

9. Townes JM, Deodhar AA, Laine ES, Smith K, Krug HE, Barkhuizen A, et al. Reactive arthritis following cultureconfirmed infections with bacterial enteric pathogens in Minnesota and Oregon: a population-based study. Ann Rheum Dis. 2008;67(12):1689-96.

10. Szamocki S, Martyn-Hemphill C, Green JSA. Reactive arthritis: cannot see, cannot pee, cannot climb a tree. Trends Urol Mens Health. 2016;7(1):17-20.

11. Hajjaj-Hassouni N, Burgos-Vargas R. Ankylosing spondylitis and reactive arthritis in the developing world. Best Pract Res Clin Rheumatol. 2008;22(4):709-23.

12. Porter CK, Riddle MS, Laird RM, Loza M, Cole S, Gariepy C, et al. Cohort profile of a US military population for evaluating predisease and disease serological biomarkers in rheumatoid and reactive arthritis: rationale, organization, design, and baseline characteristics. Contemp Clin Trials Commun. 202014 [cited 2020 May 9];17. Available from: https://www.ncbi.nlm.nih.gov/pmc/ articles/PMC6971336/.

13. Ajene AN, Fischer Walker CL, Black RE. Enteric pathogens and reactive arthritis: a systematic review of Campylobacter, Salmonella and Shigella-associated reactive arthritis. J Health Popul Nutr. 2013;31(3):299-307.

14. Denison HJ, Curtis EM, Clynes MA, Bromhead C, Dennison EM, Grainger R. The incidence of sexually acquired reactive arthritis: a systematic literature review. Vol. 35, Clinical rheumatology. Clin Rheumatol. 2016 [cited 2020 Jun 5]. Available from: https:// pubmed.ncbi.nlm.nih.gov/27480977/?from_single_result= Denison+Clin+Rheum $+2016+$ the + incidence+of + sexually+ reactive+arthritis.

15. Rachid B, El Zorkany B, Youseif E, Tikly M. Early diagnosis and treatment of ankylosing spondylitis in Africa and the Middle East. Clin Rheumatol. 2012;31(11):1633-9.

16. Kuipers JG, Sibilia J, Bas S, Gaston H, Granfors K, Vischer TL, et al. Reactive and undifferentiated arthritis in North Africa: use of PCR for detection of Chlamydia trachomatis. Clin Rheumatol. 2009;28(1):11-6.

17. Mijiyawa M, Oniankitan O, Khan MA. Spondyloarthropathies in sub-Saharan Africa [Internet]. Vol. 12, Current opinion in rheumatology. Curr Opin Rheumatol. 2000;12(4):281-6.

18. Njobvu P, McGill P, Kerr H, Jellis J, Pobee J. Spondyloarthropathy and human immunodeficiency virus infection in Zambia. $\mathrm{J}$ Rheumatol. 1998 Aug;25(8):1553-9.

19. Gérard HC, Whittum-Hudson JA, Carter JD, Hudson AP. The pathogenic role of Chlamydia in spondyloarthritis. Curr Opin Rheumatol. 2010;22(4):363-7.
20. Droemann D, Rupp J, Goldmann T, Uhlig U, Branscheid D, Vollmer E, Kujath P, Zabel P, Dalhoff K. Disparate innate immune responses to persistent and acute Chlamydia pneumoniae infection in chronic obstructive pulmonary disease. Am J Respir Crit Care Med. 2007;175(8):791-7. https://doi.org/10.1164/rcem.2006079260C.

21. Bas S, Kvien TK, Buchs N, Fulpius T, Gabay C. Lower level of synovial fluid interferon- $\gamma$ in HLA-B27-positive than in HLA-B27negative patients with Chlamydia trachomatis reactive arthritis. Rheumatology. 2003;42(3):461-7.

22. Yin Z, Braun J, Neure L, Wu P, Liu L, Eggens U, et al. Crucial role of interleukin-10/interleukin-12 balance in the regulation of the type $2 \mathrm{~T}$ helper cytokine response in reactive arthritis. Arthritis Rheum. 1997;40(10):1788-97.

23. Butrimiene I, Jarmalaite S, Ranceva J, Venalis A, Jasiuleviciute L, Zvirbliene A. Different cytokine profiles in patients with chronic and acute reactive arthritis. Rheumatology. 2004;43(10):1300-4.

24. Chaurasia S, Shasany AK, Aggarwal A, Misra R. Recombinant Salmonella typhimurium outer membrane protein $\mathrm{A}$ is recognized by synovial fluid CD8 cells and stimulates synovial fluid mononuclear cells to produce interleukin (IL)-17/IL-23 in patients with reactive arthritis and undifferentiated spondyloarthropathy. Clin Exp Immunol. 2016;185(2):210-8.

25. Bănicioiu-Covei S, Vreju A, Rosu A, Ciurea P. The importance of HLA-B27 in the evolution of reactive arthritis. Curr Health Sci J. 2019;45(4):345-52.

26. Díaz-Peña R, Blanco-Gelaz MA, Njobvu P, López-Vazquez A, Suárez-Álvarez B, López-Larrea C. Influence of HLA-B*5703 and HLA-B*1403 on susceptibility to spondyloarthropathies in the Zambian population. J Rheumatol. 2008;35(11):2236-40.

27. Kuipers JG, Bialowons A, Dollmann P, Jendro MC, Koehler L, Ikeda $\mathrm{M}$, et al. The modulation of chlamydial replication by HLA-B27 depends on the cytoplasmic domain of HLA-B27. 6.

28. HLA-B27 modulates intracellular growth of Salmonella pathogenicity island 2 mutants and production of cytokines in infected monocytic U937 cells. [cited 2020 May 25]. Available from: https://www.ncbi.nlm.nih.gov/pmc/articles/PMC3314700/.

29. Antoniou AN, Lenart I, Kriston-Vizi J, Iwawaki T, Turmaine M, McHugh K, et al. Salmonella exploits HLA-B27 and host unfolded protein responses to promote intracellular replication. Ann Rheum Dis. 2019;78(1):74-82.

30. Sieper J. Disease mechanisms in reactive arthritis. Curr Rheumatol Rep. 2004;6(2):110-6.

31. Colbert RA, Tran TM, Layh-Schmitt G. HLA-B27 misfolding and ankylosing spondylitis. Mol Immunol. 2014;57(1):44-51.

32. Kaarela K, Jäntti JK, Kotaniemi KM. Similarity between chronic reactive arthritis and ankylosing spondylitis. A 32-35-year followup study. Clin Exp Rheumatol. 2009;27(2):325-8.

33. Carter JD. Reactive arthritis: defined etiologies, emerging pathophysiology, and unresolved treatment. Infect Dis Clin North Am. 2006;20(4):827-47.

34. Lahu A, Backa T, Ismaili J, Lahu V, Saiti V. Modes of presentation of reactive arthritis based on the affected joints. Med Arch. 2015;69(1):42-5. https://doi.org/10.5455/medarh.2015.69.42-45.

35. Willkens RF, Arnett FC, Bitter T, Calin A, Fisher L, Ford DK, et al. Reiter's syndrome: evaluation of proposed criteria. Ann Rheum Dis. 1979;38 Suppl 1:suppl 8-11.

36. Lumbosacral radiographic signs in patients with previous enteroarthritis or uroarthritis - PubMed. [cited 2020 Jun 1]. Available from: https://pubmed.ncbi.nlm.nih.gov/15539414/? from single result=Mannoja $+\mathrm{A} \% 2 \mathrm{C}+$ Pekkola $+\mathrm{J} \% 2 \mathrm{C}+\mathrm{H} \% \mathrm{C} 3 \%$ $\mathrm{A} 4 \mathrm{~m} \% \mathrm{C} 3 \% \mathrm{~A} 41 \% \mathrm{C} 3 \% \mathrm{~A} 4 \mathrm{inen}+\mathrm{M} \% 2 \mathrm{C}+\mathrm{et}+\mathrm{al}+$ +Lumbosacral+ radiographic+signs+in+patients+with+previous+enteroarthritis+ or+uroarthritis.+Ann+Rheum+Dis.+2005. 
37. Courcoul A, Brinster A, Decullier E, Larbre J-P, Piperno M, Pradat $\mathrm{E}$, et al. A bicentre retrospective study of features and outcomes of patients with reactive arthritis. Joint Bone Spine. 2018;85(2):201-5.

38. Carlin EM, Ziza JM, Keat A, Janier M. 2014 European guideline on the management of sexually acquired reactive arthritis. Int J STD AIDS. 2014;25(13):901-12.

39. Kovalev IN, Il'in II. Ophthalmological aspects of Reiter's disease. Vestn Oftalmol. 1990;106(4):65-9.

40. Angulo JM, Castro F, Quispe E, Espinoza LR. A clinical profile of reactive arthritis in a peruvian series: a pilot study. J Clin Rheumatol Pract Rep Rheum Musculoskelet Dis. 2000;6(3):128-35.

41. Brown LE, Forfia P, Flynn JA. Aortic insufficiency in a patient with reactive arthritis: case report and review of the literature. HSS J Musculoskelet J Hosp Spec Surg. 2011;7(2):187-9.

42. Selmi C, Gershwin ME. Diagnosis and classification of reactive arthritis. Autoimmun Rev. 2014;13(4-5):546-9.

43. Sharma M, Sharma S, Sharma A, Sharma K. Chlamydia trachomatis associated reactive arthritis: a urinary PCR based study. Indian Dermatol Online J. 2020;11(1):21-4.

44. Kumar P, Bhakuni DS, Rastogi S. Diagnosis of Chlamydia trachomatis in patients with reactive arthritis and undifferentiated spondyloarthropathy. J Infect Dev Ctries. 2014;8(5):648-54.

45. Ozgül A, Dede I, Taskaynatan MA, Aydogan H, Kalyon TA. Clinical presentations of chlamydial and non-chlamydial reactive arthritis. Rheumatol Int. 2006;26(10):879-85.

46. García-Kutzbach A, Montenegro A, Iraheta I, Bará C, Saénz R. Epidemiology of spondyloarthropathies in Central America. Am J Med Sci. 2011;341(4):295-7.

47. Yoshimura H, Okano T, Inui K, Nakamura H. Ultrasonographic findings in a patient with reactive arthritis induced by intravesical BCG therapy for bladder cancer. J Med Ultrason 2001. 2019;46(1): $163-5$.

48. Lassus A. A comparative pilot study of azapropazone and indomethacin in the treatment of psoriatic arthritis and Reiter's disease. Curr Med Res Opin. 1976;4(1):65-9.

49. Juvakoski T, Lassus A. A double-blind cross-over evaluation of ketoprofen and indomethacin in Reiter's disease. Scand J Rheumatol. 1982;11(2):106-8.

50. Wendling D, Lukas C, Prati C, Claudepierre P, Gossec L, Goupille P, et al. 2018 update of French Society for Rheumatology (SFR) recommendations about the everyday management of patients with spondyloarthritis. Joint Bone Spine. 2018 May;85(3):275-84.

51. Barber CE, Kim J, Inman RD, Esdaile JM, James MT. Antibiotics for treatment of reactive arthritis: a systematic review and metaanalysis. J Rheumatol. 2013;40(6):916-28.

52. Kuuliala A, Julkunen H, Paimela L, Peltomaa R, Kautiainen H, Repo H, et al. Double-blind, randomized, placebo-controlled study of three-month treatment with the combination of ofloxacin and roxithromycin in recent-onset reactive arthritis. Rheumatol Int. 2013;33(11):2723-9.

53. Carter JD, Espinoza LR, Inman RD, Sneed KB, Ricca LR, Vasey $\mathrm{FB}$, et al. Combination antibiotics as a treatment for chronic
Chlamydia-induced reactive arthritis: a double-blind, placebo-controlled, prospective trial. Arthritis Rheum. 2010;62(5):1298-307.

54. Clegg DO, Reda DJ, Weisman MH, Cush JJ, Vasey FB, Schumacher HR, et al. Comparison of sulfasalazine and placebo in the treatment of reactive arthritis (Reiter's syndrome). A Department of Veterans Affairs Cooperative Study. Arthritis Rheum. 1996;39(12):2021-7.

55. Egsmose C, Hansen TM, Andersen LS, Beier JM, Christensen L, Ejstrup L, et al. Limited effect of sulphasalazine treatment in reactive arthritis. A randomised double blind placebo controlled trial. Vol. 56, Annals of the rheumatic diseases. Ann Rheum Dis. 1997 [cited 2020 Jun 29]. Available from: https://pubmed.ncbi.nlm.nih. gov/9059138/?from_single result=Egsmose $+\mathrm{C} \% 2 \mathrm{C}+$ Hansen + TM\%2C+Andersen+LS\%2 $\bar{C}+$ Beier+JM\%2C+Christensen+L\% $2 \mathrm{C}+$ Ejstrup $+\mathrm{L} \% 2 \mathrm{C}+\mathrm{et}+\mathrm{al} .+\mathrm{Limited}+\mathrm{effect}+\mathrm{of}+$ sulfasalazine+ treatment+in+reactive+arthritis. $+\mathrm{A}+$ randomized+double+blind + placebo+controlled+trial.+Ann+Rheum+Dis.+1997.

56. Courcoul A, Muis Pistor O, Tebib JG, Coury F. Early treatment of reactive arthritis with etanercept and 2 years follow-up. Joint Bone Spine. 2017;84(3):367.

57. Meyer A, Chatelus E, Wendling D, Berthelot J-M, Dernis E, Houvenagel E, et al. Safety and efficacy of anti-tumor necrosis factor $\alpha$ therapy in ten patients with recent-onset refractory reactive arthritis. Arthritis Rheum. 2011;63(5):1274-80.

58. Oili K-S, Niinisalo H, Korpilähde T, Virolainen J. Treatment of reactive arthritis with infliximab. Scand J Rheumatol. 2003;32(2): $122-4$.

59. Tanaka T, Kuwahara Y, Shima Y, Hirano T, Kawai M, Ogawa M, et al. Successful treatment of reactive arthritis with a humanized anti-interleukin-6 receptor antibody, tocilizumab. Arthritis Rheum. 2009;61(12):1762-4.

60. van Mens LJJ, van de Sande MGH, Menegatti S, Chen S, Blijdorp ICJ, de Jong HM, et al. Brief report: interleukin-17 blockade with secukinumab in peripheral spondyloarthritis impacts synovial immunopathology without compromising systemic immune responses. Arthritis Rheumatol Hoboken NJ. 2018;70(12):19942002.

61. Brinster A, Guillot X, Prati C, Wendling D. Evolution over thirty years of the profile of inpatients with reactive arthritis in a tertiary rheumatology unit. Reumatol Clínica. 2018;14(1):36-9.

62. Organisation Mondiale de la Santé (OMS): www.euro.who.int/fr/ health-topics/health-emergencies/coronavirus-covid-19/news/ news/2020/3/who-announces-covid-19-outbreak-a-pandemic. Accessed 13 May 2020

63. Saricaoglu EM, Hasanoglu I, Guner R. The first reactive arthritis case associated with COVID-19. J Med Virol. 2020;jmv.26296

Publisher's Note Springer Nature remains neutral with regard to jurisdictional claims in published maps and institutional affiliations. 